\title{
Mangrove management strategy to support fisheries in Mangunharjo Village, Semarang City
}

\author{
Irene Natalia Siahaan*, Jafron Wasiq, Kismartini \\ Master Program of Environmental Science, School of Postgraduate Studies, Diponegoro University, \\ Semarang - Indonesia
}

\begin{abstract}
Mangrove ecosystems have unique characteristics and forms and have functions and benefits as a development resource both as an economic resource and an ecological resource that has long been felt by the people who live around the coastal area. In the last few years, mangrove ecosystems in Mangunharjo Urban Village have been continuously under pressure due to human activities. The main factors causing mangrove damage, namely: (1) Pollution, (2) Conversion of mangrove ecosystems into ponds and (3) Excessive logging. Mangunharjo Village has brackish water fishery potential by having a pond area of \pm 10.45 hectares. The research method used in this research is to use a descriptive research method. The data collection technique used is the study of literature. The results showed that the condition of mangrove ecosystems in Mangunharjo Subdistrict decreased from 1990 to 1995 by $50 \%$, but began to increase again in 2002 to 2015 by $18.42 \%$. Mangrove species found in this study were Rhizophora sp, Avicennia sp, Xylocarpus $s p$ and Bruguiera sp. Mangunharjo mangrove ecosystem has the highest density of mangrove species, namely Avicennia sp. As for the results of the analysis of the extent of mangrove ecosystems on the coast of Mangunharjo with the results of fisheries production, it shows that during the period before abrasion the farmer's income was IDR 1,000,000.00 / day these conditions continue to decline to IDR $100,000.00$ to IDR 30,000.00/ day until early in 2000 .
\end{abstract}

Keywords. Mangrove ecosystems, coastal management, and pond fisheries

\section{Introduction}

Mangroves are a community that lives in muddy areas that are still affected by the tides. Mangrove forests are biological natural resources that have a variety of potential diversity that provides benefits for human life both directly and indirectly [8]. Mangroves as a component of coastal ecosystems play an important role, some of these roles or functions such as physical, chemical, biological and economic functions [12]. Mangrove forests have ecological functions, among others, as a nursery area, spawning ground, and foraging for

\footnotetext{
*Corresponding author: irenenataliac5.10@gmail.com
} 
various types of marine biota that live in it (feeding ground) [2]. Mangrove ecosystems also have a physical function, namely as an area to reduce waves and hurricanes, protectors from abrasion, silt retention and sediment capture. The optimal ecological functioning of mangrove forests can guarantee the sustainability and availability of fish populations, which are present in the waters around the ecosystem. Besides having an ecological function, mangrove forests also have important economic functions, such as providing wood, foliage as raw material for medicines, and others [1]. However, mangrove forests are vulnerable to damage if the environment is not balanced. Even the destruction of mangroves is not only caused by natural processes, but also due to human activities [10]. Mangrove forests and fishery resources have a close relationship, even according to the expert, making one ha of fish ponds in natural mangrove forests will produce $287 \mathrm{~kg}$ of fish / shrimp, but with the loss of every one ha of mangrove forests will result in a loss of 480 $\mathrm{kg}$ of fish and shrimp offshore annually [9, 14]. In the Directorate of Coastal Development DKP in 2004 describe the relationship between catching fish (Y) and mangrove forest area (X) as $Y=0.06+0.15 X$, which means an increase in mangrove area, the production fisheries also increased[7]. Explained that the presence of mangroves in good condition contributes greatly to the presence of juvenile fish, so that the declining quality and quantity of mangrove forests can have a very alarming effect, especially for the existence of fish resources in the area. Indonesia has considerable cultivation development potential, the main land which has the potential for the development of aquaculture business is located in the mangrove forest area. One area that has the potential for the development of brackish water aquaculture is the mangove ecosystem in Mangunharjo Village, Semarang City. Research by P3O LIPI and Pusfatja LAPAN in 2000 shows that the ratio of mangrove forests to ponds on the north coast of Java has been quite alarming because the existing mangrove forests are no longer able to maintain the balance of the coastal environment. In planning integrated coastal management, it is necessary to have policies to determine alternative uses based on the socio-economic conditions of the community, to choose and adopt the best ways of utilizing, to meet their needs, while securing resources for the future [4]. Along with the threat and degradation of mangroves due to human activities, it is necessary to have research, related to changes in the extent of mangroves and analyze the causes. The results of the study, are expected to provide policy recommendations or strategies for sustainable and sustainable mangrove management to support the sustainability of fisheries resources.

\section{Methodology}

The method used in this research is descriptive method, which aims to examine the problems that occur now by collecting data, compiling and classifying data, then analyzed. The data collection technique used is the study of literature.

\section{Result and Discussion}

\subsection{Result}

\subsubsection{Overview of Research Locations}

The research location is located in Mangunharjo Village, Tugu District, Semarang City. The research location is located between two villages namely Mangkang Kulon and Mangkang Wetan. The overall location of the coordinate points are: $6{ }^{0} 56$ ' 90 " LS - $6{ }^{0} 57$ ' 30 " LS and $110^{0} 18$ '90 " BT - $110^{0} 19$ '60 " BT. Mangunharjo Urban Village is an area 
that is located close to coastal waters, most of the areas where mangrove vegetation is the result of planting. According to data from the Office of Maritime Affairs and Fisheries of Central Java Province (2012) that the Mangunharjo area which has mangrove vegetation is 46.19 Ha. The location of the mangrove area in Tambakrejo can be seen in Figure 1

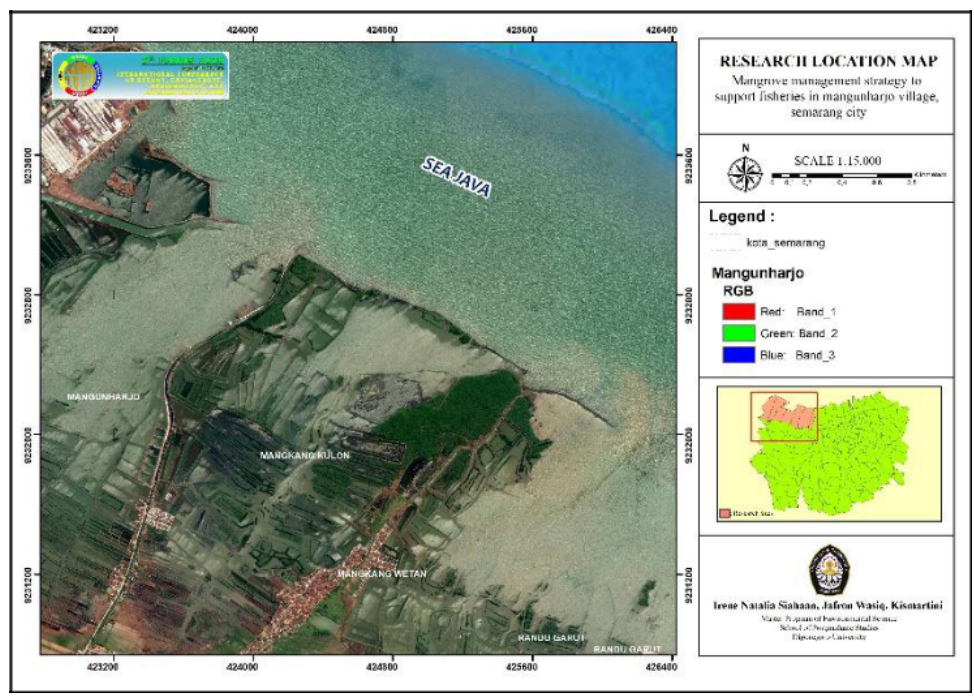

Fig. 1. The location of mangroves in Mangunharjo

\subsection{Discussion}

\subsubsection{Mangrove Vegetation Structure}

Identification of the structure and composition of mangrove ecosystems can be divided into 2 categories (major, minor) at all stations in the Mangunharjo mangrove ecosystem [6]. Major mangrove is a type of mangrove that fully lives in mangrove ecosystems in tidal areas and does not grow in other ecosystems and adapts morphology and physiology to its survival. A minor mangrove is a type of mangrove that lives on the edge of a mangrove ecosystem and is not included in the main components that make up the ecosystem. Based on data processing, the highest density level is found in Avicennia sp. Table 1 shows the composition of the mangrove ecosystem in three research stations. To see the types of mangroves found at each station can be seen in Table 1.

Table 1. Types of Mangroves in Mangunharjo [6]

\begin{tabular}{lllccc}
\hline Kategori & \multicolumn{1}{c}{ Famili } & & \multicolumn{1}{c}{ Jenis } & \multicolumn{2}{c}{ Keterangan } \\
& & & St1 & St2 & St3 \\
\hline Mayor & Avicenniaceae & Avicennia officinalis & - & + & - \\
Mayor & Avicenniaceae & Avicennia marina & - & + & + \\
Mayor & Rhizophoraceae & Rhizophora mucronata & + & - & + \\
Mayor & Rhizophoraceae & Rhizophora stylosa & + & - & - \\
Mayor & Rhizophoraceae & Rhizophora apiculata & + & - & - \\
Mayor & Rhizophoraceae & Bruguiera gymnorrhiza & + & - & - \\
Minor & Meliaceae & Xylocarpus moluccensis & - & + & - \\
\hline
\end{tabular}


The creation of ponds around the river estuary and the northern coast of Java causes a significant change in estuary vegetation. The mangrove ecosystem is only left in certain places which are very isolated or planted on the edge of the pond bordering the beach or river to prevent abrasion. The author's observations along the Mangunharjo coast show that there are fish ponds that are managed intensively far inland. Nearly all sedimentated beaches form mudflats and have mangrove ecosystems converted into pond areas. Community involvement in the rehabilitation of mangrove areas can be called "wanamina" or "silvofishery" activities. From this kind of silvofishery system by raising milkfish and wild shrimp, profits can be generated to the community. Changes in the area of mangrove in the north coast of Java have occurred because of the efforts of the government and the community in the management of ponds that are environmentally sound through the intercropping ponds program. From these efforts, it appears that there has been an increase in mangrove areas with an area of now \pm 46.19 ha. Rehabilitation efforts in the Mangunharjo coastal area have been carried out by several parties both from the government and from $\mathrm{NGO}_{s}$, unfortunately these efforts are carried out individually without any collaboration that makes the rehabilitation efforts can be maintained. Besides that, after the rehabilitation there is no monitoring to monitor the progress of the rehabilitation results. Many remnants of mangrove planting survived from the beginning and many also died. Mangrove seedlings planted in the Mangunharjo coastal area usually die due to crab pests and coastal abrasion. Based on the analysis of perception shows that the Mangunharjo coastal communities understand the importance of mangrove areas in their survival. The Mangunharjo coastal community agrees that there is a need for rules in managing mangrove areas, and violations of the rules for managing mangrove areas need to be given sanctions or penalties. Public knowledge has so far been lacking about the existence of rules and sanctions in the management of mangrove areas. The community in general must be given knowledge in the form of counseling and training on mangrove management for the preservation of mangrove areas. Considering the vulnerability of the existence of man grove forests and the activities of the people who live around mangrove forests in protecting their natural resources, the role of the community in preserving and even developing mangrove forests into an environmental forest supporting the availability of marine natural resources is very important [5].

\subsubsection{Fisheries Productivity Associated with Mangroves}

Mangrove forests function as a place to find food, shelter, spawn and grow for various types of aquatic animals such as fish and shrimp. It is also a place of life for protected animals. The types of fish that utilize the forest area as a shelter are white snapper (Lates calcarifer), milkfish (Chanos chanos), mullet (Mugil sp), Tiger shrimp (Panaeus monodon), white shrimp ( $P$. Merguensis or $P$. indicus ), giant prawns or satang shrimp (Macrobrachium rosenbergii), and crab (Scylla serrata. According to Chong et al (1990), mangrove waters are a treatment area and a place to eat for a number of species of fish and shrimp. Mangrove waters are a place to look for food at high tides for economical and noneconomic fish. Meanwhile, according to the results of research [9] showed that there was a significant relationship between the extent of mangrove areas with aquaculture production. The association of mangroves with fisheries productivity has been widely reported. Clearing of mangrove ecosystems is always followed by decreasing fish and shrimp catches in the surrounding coastal waters [9], including clearing of mangroves for aquaculture. The refore it is necessary to have an integrated management between mangrove forest and fisheries managers, so that opportunities are opened for aquaculture and mariculture in a sustainable manner [3]. The extent of mangrove areas with aquaculture production has a significant relationship. As the mangrove area increases, fishery 
production also increases by forming the equation: $Y=0.06+0.15 X$, In that equation, $\mathrm{Y}$ is catch production in tons / year, and $\mathrm{X}$ is the area of mangrove in ha (DG of Coastal Development Directorate General) 2004). Fishing communities living around mangrove forest areas with an effective number of fishing days per year 240 days ( 8 months) can capture fish with a production of 24,000 fish / ha / year in an effective area of fish habitat about 60 percent of the total area of mangrove forests so that the role of mangrove forests the results of this fish can be enjoyed by the local community. Besides fish, the community also gets mangrove forest products from crab catches. Crab caught by the community in the catchment area is around \pm 0.2 ha with an effective number of fishing activities per year is 240 days ( 8 months) harvesting as much as $3,000 \mathrm{~kg} /$ ha / year with a crab price of IDR $55,000 / \mathrm{kg}$, which is the effective area of crab habitat about 50 percent of the total area of mangrove forests. As for the results of the analysis of the extent of mangrove ecosystems in the mangunharjo coast with fisheries production results, it shows that during the period before abrasion farmer income was IDR 1,000,000.00 / day the condition continues to decline to IDR 100,000.00 to IDR 30,000.00 / day until the beginning of 2000 [13].

\subsubsection{Mangrove Management Strategy}

\subsubsection{Conservation}

Mangrove management strategies to support fisheries on the Mangunharjo coast prioritize conservation and rehabilitation. Rehabilitation of the area is needed by planting mangroves, this is because the ecology of mangroves both physically, ecologically, socially, and economically is very beneficial for coastal areas and the inhabitants of the area. Planting can be done with the zoning system, namely the green belt area, river channel, pond cultivation area, and the border area of ponds and rice fields [11].

\subsubsection{Ecotourism Development}

Based on the biophysical conditions and the presence of the main habitat accompanied by the presence of biodiversity in it, the mangrove ecosystem on the coast of Mangunharjo can also be used as a beach tour. The characteristics of the land that is in transition between land and sea are unique in several ways. The tourists also get lessons about the environment directly from nature. Mangrove forest management policy as a coastal tourism will be able to preserve the environment and improve the welfare of local communities, in addition to contributing regional budget revenues to the Semarang City Government.

\subsubsection{Community development}

In the management of mangrove forests, one thing that needs to be considered is by making the community a major component in the management and preservation of mangrove forests. Therefore, people's perception or perspective on the existence of mangrove forests needs to be directed to the perspective of how important the mangrove forest resources are. One way is community-based management through its application with community empowerment in managing mangrove ecosystems. 


\subsubsection{Education and training}

It should also be noted that in the mangrove ecosystem area besides mangrove forest areas there are also areas or land that are not mangrove forest areas and are usually managed by local communities (landowners) that are used for aquaculture, agriculture, and so on. For this reason, participatory mangrove ecosystem management and monitoring patterns are one appropriate solution.

\section{Conclusion}

Mangrove ecosystem management strategies to support fisheries on the Mangunharjo coast get an alternative management strategy that is a priority is the conservation or rehabilitation of mangroves and then followed by conducting Ecotourism Development, Community Empowerment and Education and Training.

\section{References}

[1] Alikodra HS. 1998. Mangrove Forest Management Policy Seen from the Environment, in the Proceedings of Seminar VI of the Mangrove Ecosystem. Jakarta: LIPI. Page: 33-43.

[2] Bengen D G. 2000. Technical Guidelines for Introduction and Management of Mangrove Ecosystems. Center for Coastal and Ocean Resource Study. Bogor Agricultural Institute. 58 pages.

[3] Cairo JG, Guebas FD, Bosire J, Koedam N. 2001. Restoration and Management of Mangrove Systems a lesson for and from the East African Region. South African Journal and Botany. Volume 67. (2001).

[4] Chong V C, Sesakumar A, Leh M U C, Cruz R D. 1990. The Fish and Prawn Communities of a Malaysian Coastal Mangrove System with Comparisons to Adjacent Mud Flats and Inshore Waters. Est. Coast. Shelf Sci. 31: 703-722.

[5] Cie Y, Wisudo S H, Purbayanto A. 2010. Participation of Fishing Communities in Utilizing Mangrove Areas for Capture Fisheries in North Halmahera. Akses with http: // www. Repository.ipb.ac.id. September 10, (2012).

[6] Halim (2019). Potential Environmental Services Based on Estimation of Upright Carbon and Sediment Reserves in the Mangunharjo Mangrove Ecosystem. [THESIS]. Diponegoro University, 82 pages.

[7] Kawaroe M, Bengen DG, Eidman M, Boer M. 2001. The contribution of mangrove ecosystems to the structure of fish communities in the North Coast of Subang Regency, West Java. Journal of Coastal and Ocean. 3 (3).

[8] Kustanti A. 2011. Mangrove Forest Management. Bogor (ID). PT. Bogor Agricultural Institute.

[9] Martosubroto P N, Naamin. 1985. Fisheries Resources and Fish Flour Industry. Proceedings of the Fish Flour Technical Meeting. Center for Agriculture Research and Development. Agricultural Research and Development Agency. Ministry of Agriculture, Jakarta.

[10] Pramudji. 2000. 'Impact of Human Behavior on Mangrove Forest Ecosystems in Indonesia 'in Osean. Volume XXV, Number 2, 2000; 13-20.

[11] Sacred. 2014. Mangrove Planting as One of Land and Environmental Rehabilitation Efforts in the Coastal Areas of the North Coast of Karawang Regency. Scientific Journal of Solutions. (1) 1: 1.

[12] Saparinto C. 2007. Mangrove Ecosystem Empowerment. Dahara Prize. Semarang, 236 pages. 
[13] Setiyowati, 2017. Mangrove Resource Economic Valuation in Mangunharjo Village, Tugu District, Semarang City. Indonesian Journal of Fisheries Science and Technology. 12 (1): 67-74.

[14] Turner R.E. 1977. Intertidal Vegetation and Commercial Yields of Penaeid Shrimp. Trans. Am Fish Soc. 106: 411-416. 